\title{
PENGEMBANGAN E-MODUL DALAM PEMBELAJARAN MATEMATIKA SMA BERBASIS ANDROID
}

\section{(DEVELOPMENT OF E-MODULES IN LEARNING MATH HIGH SCHOOL ANDROID BASED)}

\author{
Dudi Wahyudi ${ }^{1}$ \\ ${ }^{1}$ SMAN 1 Rangkasbitung, dudiwahyudi.mn02@gmail.com
}

\begin{abstract}
Abstrak
Proses pembuatan media belajar ini yang terkadang memiliki kendala dalam pencapaian tujuan. Media belajar biasanya dibuat oleh guru sehingga siswa terkadang tidak dapat memahami makna atau konten yang disampaikan. Sebaliknya apabila konten dibuat secara bersama dalam sebuah aplikasi maka akan menghasilkan produk bersama yang dapat dipahami bersama. Tujuannya adalah (1) mengembangkan e-Modul dalam pembelajaran matematika SMA berbasis android; (2) menanamkan kecakapan literasi digital bagi peserta didik melalui $e$-Modul dan (3) mengetahui gambaran dan respon peserta didik dalam pengembangan e-Modul dalam pembelajaran matematika materi Lingkaran. Model pengembangan yang digunakan mengikuti alur Thiagarajan. Model pengembangan 4-D terdiri dari 4 tahap yaitu Define, Design, Develop, dan Disseminate atau diadaptasikan menjadi model 4-P, yaitu pendefinisian, perancangan, pengembangan, dan penyebaran. Berdasarkan uji coba terbatas, disimpulkan bahwa secara umum e-Modul diterima dan dapat digunakan oleh peserta didik dengan baik. eModul praktis dan mudah dijalankan. Berdasarkan hasil respon siswa, pembelajaran menggunakan aplikasi e-Modul menanamkan kecakapan literasi digital bagi peserta didik melalui gambaran aktivitas siswa dan guru. Pembelajaran menggunakan e-Modul membuat ketertarikan mengikuti pembelajaran di kelas sebesar 93,33\% dan 83,33\% (hampir seluruhnya).
\end{abstract}

Kata kunci : android, e-Modul.

\begin{abstract}
The process of making this learning media sometimes has obstacles in achieving goals. Learning media are usually made by the teacher so students sometimes cannot understand the meaning or content conveyed. Conversely, if content is created together in an application it will produce a shared product that can be understood together. The objectives are (1) to develop eModules in Android-based high school mathematics learning; (2) instilling digital literacy skills for students through e-Modules and (3) knowing the images and responses of students in developing e-Modules in mathematics learning Circle material. The development model used follows the flow of Thiagarajan. The 4-D development model consists of 4 stages, namely Define, Design, Develop, and Disseminate or be adapted into a 4-P model, which is defining, designing, developing, and distributing. Based on limited trials, it was concluded that in general e-Modules were accepted and could be used by students well. e-Modules are practical and easy to run. Based on the results of student responses, learning using the e-Module application instills digital literacy skills for students through an overview of student and
\end{abstract}


teacher activities. Learning using e-Modules makes interest in participating in learning in the classroom by $93.33 \%$ and $83.33 \%$ (almost all).

Keywords: android, e-Module.

\section{PENDAHULUAN}

"Pendidikan adalah daya upaya untuk memajukan bertumbuhnya budi pekerti (kekuatan batin,karakter), pikiran (intelec) dan tubuh anak. Bagianbagian itu tidak boleh dipisahkan agar kita dapat memajukan kesempurnaan hidup anak-anak kita" (Kemdikbud RI, 2016).

Demikian juga laporan Delors untuk pendidikan abad XXI, sebagaimana tercantum dalam buku Pembelajaran: Harta Karun di Dalamnya, menegaskan bahwa pendidikan abad XXI bersandar pada lima tiang pembelajaran sejagat (five pillar of learning), yaitu learning to know, learning to do, learning to live together, dan learning to beserta learning to transform for oneself and society. (Wahyudi, 2012). Selain itu, Undang-Undang Nomor 20 Tahun 2003 tentang Sistem Pendidikan Nasional telah menegaskan bahwa "Pendidikan nasional berfungsi mengembangkan kemampuan dan membentuk watak serta peradaban bangsa yang bermartabat dalam rangka mencerdaskan kehidupan bangsa, bertujuan untuk berkembangnya potensi peserta didik agar menjadi manusia yang beriman dan bertakwa kepada Tuhan Yang Maha Esa, berakhlak mulia, sehat, berilmu, cakap, kreatif, mandiri, dan menjadi warga negara yang demokratis serta bertanggung jawab" (Pranowo, 2017).

Proses belajar mengajar adalah suatu seni yang indah sebagai bagian dari proses melukis masa depan peserta didik (Borg \& Gall, 1983). Lukisan tidak pernah ada yang salah hanya perspektif yang membuat lukisan tersebut punya nilai keindahan atau tidak. Proses melukis tersebut merupakan proses yang sangat berat jika tidak memiliki kompetensi dan daya dukung yang tepat, proses inilah yang menjadi suatu pengalaman luar biasa. Konsep pendidikan tidak hanya sebatas melukis tetapi membawa kebermanfaatan dalam lukisan tersebut, pelaku dan penikmat lukisan tersebut memiliki peranan masing-masing.

Keberhasilan siswa dalam belajar dapat dipengaruhi oleh banyak faktor, baik yang sifatnya intrinsik, dari dalam diri siswa itu sendiri atau pun yang sifatnya ekstrinsik, yaitu faktor dari luar diri siswa (Oktaviyanthi, 2007). Di antara faktor-faktor tersebut, seperti yang dikemukakan oleh Ruseffendi (1991) adalah cara penyajian materi dan suasana pengajaran. Beberapa komponen belajar mengajar yang memiliki peranan penting diantaranya adalah inovasi dalam pembelajaran di kelas. Inovasi tidak selamanya bergelut dengan konsep baru, karena pada dasarnya yang sudah adapun bisa menjadi luarbiasa jika dikemas dalam suatu hal keterbaruan dan media yang tepat sesuai kemampuan perkembangan abad 21. Daya dukung kegiatan belajar mengajar diantaranya adalah Guru dan peserta didik, diantara keduanya ada penghubung yang disebut kurikulum, sebagai penghubung tentunya harus memiliki fungsi yang baik. 

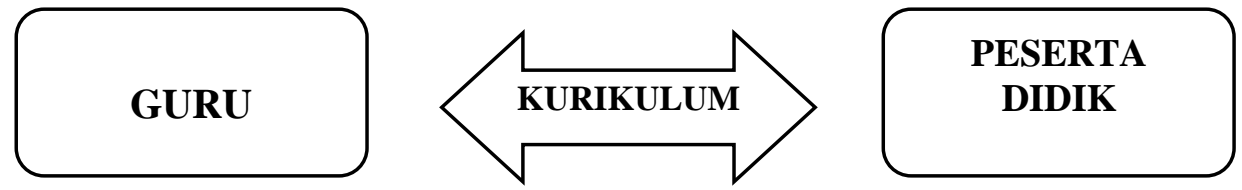

Gambar 1. Koneksi antara Guru dan Peserta didik

Koneksi tersebut akan harmonis jika kurikulum didesain untuk bisa menjembatani dua peranan tadi. Kekuatan kurikulum itu diantaranya adalah bahan ajar, konten belajar, media belajar, karakter belajar, model belajar dan keterbaruan belajar. Ketika hal itu muncul dalam proses belajar di kelas maka akan terjalin komunikasi baik dalam pencapaian tujuan belajar.

Untuk mengoptimalkan potensi dua peran tadi baik sebagai Guru maupun peserta didik maka terus dikembangkan salah satu kekuatan kurikulum yaitu media belajar. Media belajar yang baik tentu saja yang mengikuti perkembangan pola fikir dan kemajuan penguasaan teknologi peserta didik.

Proses pembuatan media belajar ini yang terkadang memiliki kendala dalam pencapaian tujuan. Media belajar biasanya dibuat oleh Guru sehingga siswa terkadang tidak dapat memahami makna atau konten yang disampaikan (Oktaviyanthi, Safaah, \& Agus, 2017). Sebaliknya apabila konten dibuat secara bersama dalam sebuah aplikasi maka akan menghasilkan produk bersama yang dapat dipahami bersama.

Proses belajar dan pembelajaran tidak sebatas pencapaian kurikulum dalam segi kompetensi dasar, tetapi lebih bermakna apabila memiliki penguatan pendidikan karakter baik bagi guru mapun peserta didik (Dryden \& Jeannette, 2000). Proses pemahaman pada materi pelajaran sebaiknya dapat dirasakan oleh peserta didik maka seyogyanya peserta didik dapat terlibat dalam proses belajar sehingga mampu menumbuhkan karakter positif dalam belajar diantaranya pantang menyerah, kerjasama dan mandiri.

Berdasarkan hal tersebut, perlu dikembangkan suatu aktivitas yang dapat menjembatani proses belajar sesuai perkembangan pendidikan abad 21, diantaranya pemanfaatan teknologi informasi dan komunikasi dalam pembelajaran matematika di SMAN 1 Rangkasbitung, sebagai pengembangan produk naskah digital e-Modul bagi siswa berbasis Personal Computer dan Android. Sejalan dengan penelitian ini, rumusan masalahnya adalah: (1) apakah pengembangan eModul dalam pembelajaran matematika mampu menanamkan kecakapan literasi digital bagi peserta didik; (2) bagaimana pengembangan eModul dalam pembelajaran matematika SMA berbasis android; (3) bagaimana gambaran dan respon peserta didik dalam pengembangan eModul dalam pembelajaran matematika materi Lingkaran.

Berdasarkan latarbelakang tersebut dapat dirumuskan tujuan penelitian ini adalah (1) Mengembangkan $e$-Modul dalam pembelajaran matematika SMA berbasis android; (2) Menanamkan kecakapan literasi digital bagi peserta didik melalui e-Modul; (3) Mengetahui gambaran dan respon peserta didik dalam pengembangan $e$-Modul dalam pembelajaran matematika materi Lingkaran.

\section{KAJIAN TEORI \\ Naskah Digital}

Naskah digital merupakan naskah yang dapat dibaca, didengar dan 
ditampilkan pada perangkat digital baik desktop maupun smartphone. Naskah dapat berupa buku, modul, bahan ajar yang berupa teks atau kombinasi dari tulisan, audio maupun video yang ditampilkan dalam satu kesatuan utuh sebagai suatu naskah. Seringkali kita mendengar istilah $e$-modul, e-book, e-learning yang semuanya itu disajikan sebagai suatu naskah digital dengan menggunakan berbagai aplikasi.

Format naskah digital secara umum dapat kita bedakan menjadi dua bagian yaitu:

a. Naskah digital Tanpa Multimedia atau secara umum disebut naskah total sebuah teks atau tulisan tanpa ada kombinasi dari suara (audio) maupun gambar (video). Misal: doc, docx, pdf, dan sebagainya.

b. Naskah digital Dengan Multimedia atau secara umum disebut naskah yang dikombinasikan dengan suara (audio) maupun gambar (video). Misal: ePub, flash, dll.

Salah satu naskah mulitimedia yang akan dibahas pada buku ini adalah tentang e-PUB (electronic publication).

\section{Aplikasi Sigil}

Sigil adalah software pembuat naskah digital gratisan yang multi platform (Windows dan iOS). Software ini juga memiliki fitur untuk menambahkan cover picture, daftar isi, dan indeks. Bisa juga menambahkan dan mengubah konten pada naskah digital. File masukan yang didukung adalah HTML dan e-PUB, sedangkan file keluaran yang didukung hanya e-PUB. Software ini menyediakan fasilitas untuk mengubah styling font, menambah audio, video, dan gambar pada naskah digital. Setelah selesai melakukan proses editing, simpan naskah digital dalam format e-PUB (Tamimudin, 2013).

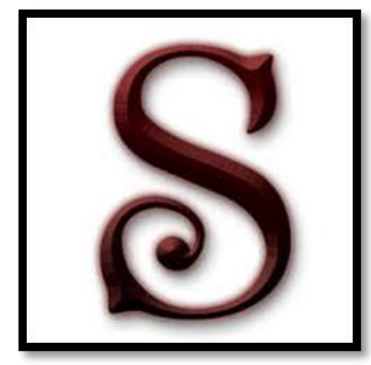

Gambar 2. Ikon Sigil

\section{Aplikasi Azardi}

Azardi adalah salah satu app pada google crome yang dapat membuka file e-PUB (naskah digital) di Personal Computer (PC).

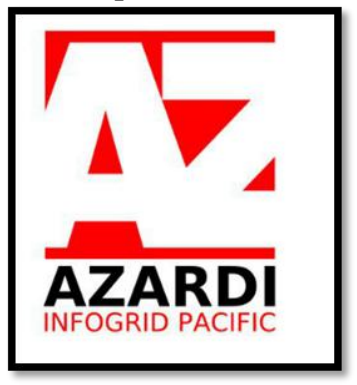

Gambar 3. Ikon Azardi 


\section{Aplikasi Rasily}

Reasily adalah salah satu app yang dapat membuka file ePub (naskah digital) di Android.

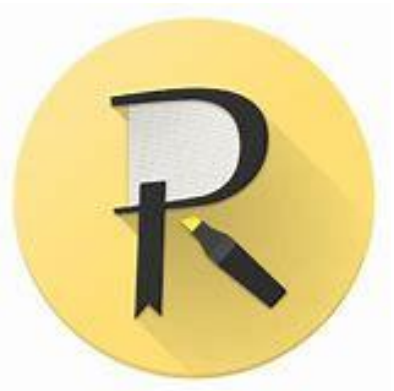

Gambar 4. Ikon Reasily

\section{METODE PENELITIAN}

Model pengembangan yang digunakan mengikuti alur dari Thiagarajan (1974). Model pengembangan 4-D terdiri dari 4 tahap yaitu Define, Design, Develop, dan Disseminate atau diadaptasikan menjadi model 4-P, yaitu pendefinisian, perancangan, pengembangan, dan penyebaran (Sugiyono, 2015). Model 4-D inilah yang digunakan dalam penelitian ini.

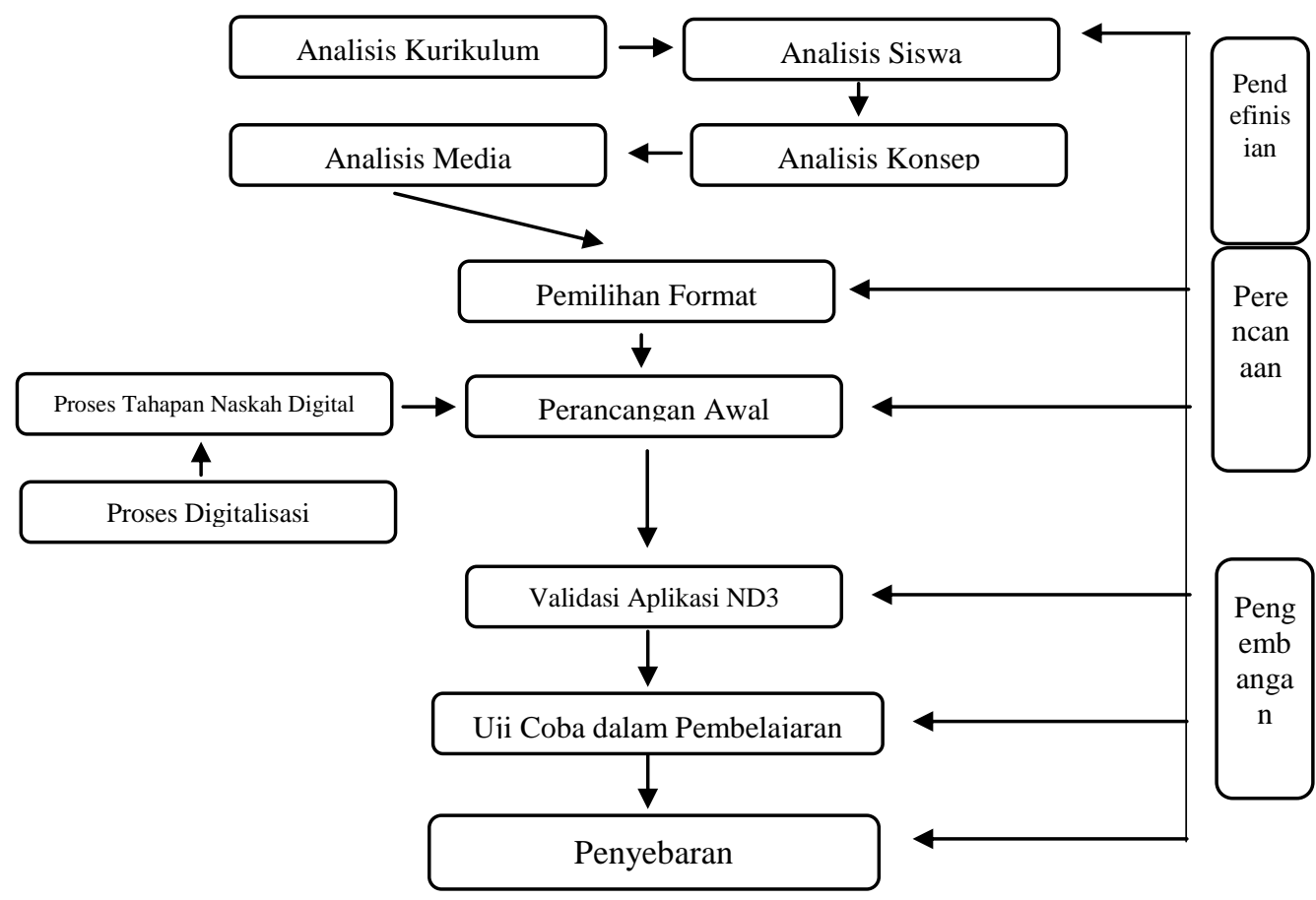

Gambar 5. Langkah Pengembangan Aplikasi e-Modul dengan Model 4-D (Thyagarajan et al., 1974)

\section{Tahap define (Pendefinisian)}

Pada tahap ini dilakukan kajian jenis data dan sumber data atau hasil analisis yang berisi tentang kajian kesulitas belajar, potensi sumber daya, kajian Kompetensi Dasar (KD) dan pembuatan Rencana Pelaksanaan Pembelajaran (RPP). Pengumpulan data awal dilakukan melalui wawancara dengan rekan guru 
mata pelajaran matematika terkait analisis kurikulum, media pembelajaran dan topik atau materi yang seringkali ditemukan permasalahan. Berdasarkan hasil data awal diperoleh beberapa hal terkait penggunaan media pembelajaran yang belum efektif dan belum mengakomodir pemanfaatan teknologi dalam pembelajaran.

Tabel 1. Jenis dan Sumber Data Tahap Pendefinisian (Define)

\begin{tabular}{|c|c|c|}
\hline No & Jenis Data & Sumber Data/Hasil Analisis \\
\hline 1 & $\begin{array}{l}\text { Kajian kesulitan belajar } \\
\text { topik lingkaran. }\end{array}$ & $\begin{array}{l}\text { - Referensi hasil penelitian nasional } \\
\text { dan internasional. } \\
\text { - Wawancara dengan guru mata } \\
\text { pelajaran matematika. }\end{array}$ \\
\hline 2 & $\begin{array}{l}\text { Potensi sumber daya (guru, } \\
\text { siswa dan sarana \& } \\
\text { prasarana IT) }\end{array}$ & Hasil observasi lapangan \\
\hline 3 & $\begin{array}{l}\text { Kajian muatan Kompetensi } \\
\text { Dasar (KD) dan Rencana } \\
\text { Pelaksanaan Pembelajaran } \\
\text { (RPP) }\end{array}$ & $\begin{array}{l}\text { - Permendikbud nomor } 21 \text { tahun } \\
2016 \\
\text { - } \text { Musyawarah Guru Mata Pelajaran } \\
\text { (MGMP) matematika SMAN } 1 \\
\text { Rangkasbitung }\end{array}$ \\
\hline 4 & $\begin{array}{l}\text { Kajian media pembelajaran } \\
\text { yang digunakan. }\end{array}$ & $\begin{array}{l}\text { - Media pembelajaran yang } \\
\text { digunakan belum variatif. } \\
\text { - Belum mengakomodasi } \\
\text { pemanfaatan teknologi. }\end{array}$ \\
\hline
\end{tabular}

\section{Tahap design (Perancangan)}

Setelah memperoleh gambaran awal, selanjutnya dilakukan perancangan media pembelajaran yang akan digunakan yaitu modul elektronik atau seringkali disebut eModul. Tahap perancangan selanjutnya yaitu pemilihan format yaitu ePub yang nantinya dapat dibaca di Personal Computer dan android. Setelah pemilihan format selesai tahap selanjutnya menyiapkan naskah digital dalam bentuk file word yang nantinya akan diubah menjadi file HTML dan ePub.

Tabel 2. Perancangan e-Modul

\begin{tabular}{cll}
\hline File Program & \multicolumn{1}{c}{ Isi } & \multicolumn{1}{c}{ Keterangan } \\
\hline Pemilihan Format & $\begin{array}{l}\text { Format yang digunakan adalah } \\
\text { berbasis android dana tau dapat } \\
\text { dibuka di PC (file e-Pub) }\end{array}$ & $\begin{array}{l}\text { e-Pub adalah sebuah } \\
\text { software yang } \\
\text { digunakan untuk } \\
\text { publikasi naskah } \\
\text { digital. }\end{array}$
\end{tabular}

Tahap pembuatan Naskah Digital

Perancangan $\quad$ Tahap ini meliputi pembuatan Pengisian aplikasi e-

Awal awal e-Modul dari beberapa file, modul dapat direvisi yaitu:

- Word dan disesuaikan

- HTML setelah proses ujicoba 
- E-Pub

Menu e-Pub

\begin{tabular}{ll}
\hline Pengembangan Proses & Sebagai pencatat \\
penggunaan aplikasi terpantau & penggunaan aplikasi \\
melalui blog. & secara sederhana.
\end{tabular}

\section{Tahap development (Pengembangan)}

Tahap ini lebih fokus pada pengisian konten sesuai dengan sistematika sebuah modul yang terdiri dari bagian awal, pendahuluan, pembelajaran, latihan dan evaluasi serta daftar pustaka. Setelah selesai pengisian konten, selanjutnya dilakukan ujicoba terbatas yang dilakukan di sekolah dan MGMP Matematika

Tabel 3. Pengembangan $e$-Modul

\section{COVER}

Judul modul

Nama Mata Pelajaran

Topik/Materi Pembelajaran

Kelas

Penulis

Daftar Isi

Glosarium

\section{PENDAHULUAN}

KD dan IPK

Deskripsi singkat materi, rasionalisasi, dan relevansi

Prasyarat

Petunjuk Penggunaan e-Modul

\section{PEMBELAJARAN}

Kegiatan Pembelajaran

Tujuan

Uraian Materi

Rangkuman

Tugas

Latihan

Penilaian Diri

III. EVALUASI

\section{DAFTAR PUSTAKA}

LAMPIRAN

\section{Uji Coba Pengembangan e-Modul}

1. Uji Coba Terbatas

2. Gambaran Aktivitas Siswa dan Guru dalam Pembelajaran Menggunakan eModul

3. Respon Siswa Terhadap Pembelajaran Menggunakan e-Modul

\section{Tahap disseminate (Penyebaran)}

Kegiatan ini merupakan hasil dari 3 tahapan tadi yaitu berupa pemanfaatan dalam pembelajaran dan seminar di sekolah.

Tabel 4. Penyebaran $e$-Modul

\begin{tabular}{lll}
\multicolumn{1}{c}{ Kegiatan } & \multicolumn{1}{c}{ Sasaran } & \multicolumn{1}{c}{$\begin{array}{c}\text { Pelaksanaan } \\
\text { Tanggal }\end{array}$} \\
\hline $\begin{array}{l}\text { 1. Pemanfaatan lebih } \\
\text { luas e-Modul dalam } \\
\text { pembelajaran SMA } \\
\text { berbasis android }\end{array}$ & Kelas XI MIPA & Februari - \\
2. Seminar Pembuatan & Semua warga SMAN 1 & Juni 2018 \\
\hline
\end{tabular}


E-Modul di SMAN $1 \quad$ Rangkasbitung

Rangkasbitung

\section{HASIL DAN PEMBAHASAN}

1. Mengembangkan e-Modul dalam Pembelajaran Matematika SMA

Berbasis Android.

Untuk kualitas dan keabsahan media yang dikembangkan, selanjutnya akan dilakukan validasi ahli. Sebelum divalidasi ahli, melalui kegiatan Focus Group Discussion (FGD) yang diikuti oleh calon pengguna (guru dan siswa), saran dan kritik membangun terkait prototype eModul dikumpulkan untuk bahan pengembangan pada tahap awal. Validasi dilakukan oleh tiga orang ahli, yaitu ahli pendidikan matematika, ahli media (guru TIK), dan ahli praktisi (guru mata pelajaran matematika). Skor hasil validasi ahli sebesar 4 dan 5 (dalam skala 5) memiliki kategori sangat baik. Daftar distribusi frekuensi penilaian dari validator disajikan pada Tabel 5berikut ini.

Tabel 5. Distribusi Frekuensi Validasi Ahli

\begin{tabular}{lcc}
\hline Kriteria & Frekuensi & $\%$ \\
\hline Sangat & 40 & 74,07 \\
baik & 14 & 25,93 \\
Baik & 0 & 0,00 \\
Cukup & 0 & 0,00 \\
Kurang & 0 & 0,00 \\
Sangat & 54 & 100,00 \\
kurang & Jumlah &
\end{tabular}

(diambil dari 18 item pernyataan)

Berdasarkan data pada Tabel 5 terlihat bahwa berdasarkan indikatorindikator penilaian yang telah ditetapkan, para ahli menyebut aplikasi eModul berada pada kategori sangat baik $(74,08 \%)$ dan baik $(25,93 \%)$. Secara umum, komentar para ahli menyatakan bahwa aplikasi eModul menarik dan dapat digunakan sebagai media pembelajaran matematika topik Lingkaran. Beberapa temuan dan saran perbaikan yang diutarakan diantaranya: petunjuk e-Modul hendaknya dibuat lebih detail sehingga lebih jelas untuk pengguna, tambahkan informasi umum tentang $e$-Modul, aplikasi belum menampilkan soal interaktif.

\section{Menanamkan Kecakapan Literasi Digital bagi Peserta Didik Melalui Gambaran Aktivitas Siswa dan Guru dalam Pembelajaran Menggunakan $\boldsymbol{e}$-Modul}

Setelah e-Modul divalidasi oleh ahli dan dinyatakan layak dengan kisaran hasil penilaian bernilai baik atau sangat baik, selanjutnya $e$-Modul dinilai juga oleh siswa untuk memberikan penilaian tampilan secara umum dari sudut pandang sebagai pengguna. Penilaian dilakukan dengan cara pemberian angket yang berisi beberapa pernyataan mengenai $e$-Modul. Uji coba dilakukan pada kelompok kecil, yaitu kepada 30 orang siswa kelas XI .

Secara umum, respon siswa terhadap $e$-Modul dapat digunakan sebagai alternatif media belajar materi Lingkaran dengan cara menyenangkan sebanyak 
$76,67 \%$ siswa menyatakan sangat setuju bahwa tampilan awal $e$-Modul menarik sehingga penasaran untuk segera mencobanya, dan $10 \%$ menyatakan setuju. Sebanyak 90\% siswa menyatakan sangat setuju dan e-Modul dapat meningkatkan motivasi belajar matematika responden menjawab 96,67\% sangat setuju. Rekapitulasi respon siswa terhadap e-Modul secara lengkap disajikan pada Lampiran. Beberapa saran dan masukan dari siswa sebagai pengguna diakomodasi untuk tahap revisi akhir.

\section{Respon Siswa Terhadap Pembelajaran Menggunakan e-Modul}

Untuk mengetahui respon siswa terhadap pembelajaran, siswa diberikan angket setelah pembelajaran berlangsung. Pernyataan-pernyataan dalam angket mencakup hal-hal yang berkaitan dengan pembelajaran menggunakan eModul yang telah dilakukan.

Secara umum, respon siswa terhadap pembelajaran matematika menggunakan $e$-Modul membuat ketertarikan mengikuti pembelajaran di kelas sebesar 93,33\% (Hampir seluruhnya) dan 83,33\% (Hampir seluruhnya) peserta didik tidak malas mengikuti kegiatan pembelajaran menggunakan e-Modul serta sebagian besar $(63,33 \%)$ peserta didik aktif dan antusias mengikuti pembelajaran menggunakan $e$-Modul.

\section{Nilai Penting dan Kebaruan Penelitian yang telah dilaksanakan}

Dalam perkembangannya pemanfaatan eModul di SMAN 1 Rangkasbitung telah memberikan ruang kreatif dan penumbuhan karakter bagi peserta didik dan guru diantaranya:

a. Rekan guru berkeinginan membuat naskah digital untuk kepentingan pembelajaran.

b. Pemanfaatan android sebagai media belajar dapat diimplementasikan di luar sekolah.

c. Pola kemandirian siswa dalam menjalankan eModul terlihat dengan beberapa laporan peserta didik yang mencoba beberapa kali menjalankan kuis untuk memperoleh nilai maksimal (100).

d. Berbagai masukan tentang eModul memotivasi pengembang dalam menciptakan versi baru dan materi lainnya.

e. Memotivasi pengembang membuat buku tentang naskah digital (membuat e-modul).

\section{SIMPULAN DAN SARAN}

Kesimpulan yang diperoleh dari penelitian ini yakni:

1. Berdasarkan hasil uji validasi ahli media, ahli materi, dan ahli praktisi disimpulkan bahwa eModul 74,07\% dinyatakan "Sangat Baik" dan 25,93\% dinyakan "Baik".

2. Berdasarkan hasil respon siswa, pembelajaran menggunakan e-Modul sebanyak $90 \%$ siswa menyatakan sangat setuju dan e-Modul dapat meningkatkan motivasi belajar matematika responden menjawab 96,67\% sangat setuju.

3. Berdasarkan hasil respon siswa, pembelajaran menggunakan eModul menanamkan kecakapan literasi digital bagi peserta didik melalui gambaran aktivitas siswa dan guru. Pembelajaran menggunakan e-Modul membuat 
ketertarikan mengikuti pembelajaran di kelas sebesar 93,33\% (Hampir seluruhnya) dan $83,33 \%$ (Hampir seluruhnya) peserta didik tidak malas mengikuti kegiatan pembelajaran menggunakan e-Modul serta sebagian besar $(63,33 \%)$ peserta didik aktif dan antusias mengikuti pembelajaran menggunakan $e$-Modul.

Selama proses penelitian dan pengembangan yang telah dilalui melalui prosedur 4-D Models, ditemukan beberapa kekurangan dan kelebihan, maka untuk perbaikan ke depan diajukan beberapa saran sebagai berikut:

1. e-Modul dapat dioptimalkan sebagai lembar kerja yang bisa diakses seecara online oleh peserta didik.

2. Setelah e-Modul dapat dioptimalkan maka lakukan uji efektivitas penggunaannya.

\section{DAFTAR RUJUKAN}

Borg, W.R., \& Gall, M.D. (1983). Educational Research: An Introduction, Fifth Edition. New York: Longman.

Dryden, G., \& Jeannette, V. (2000). Revolusi Cara Belajar: The Learning Revolution Bagian I. Bandung: Kaifa.

Kemdikbud RI. (2016). Implementasi Pengembangan Kecakapan Abad 21 Dalam Perencanaan Pelaksanaan Pembelajaran (RPP). Jakarta: Kemdikbud.

Oktaviyanthi, R. (2007). Hibingan Pola Kepribadian dan Dominasi Hemisfer Terhadap Kemampuan Membaca Matematika Siswa. Skripsi Universitas Pendidikan Indonesia. Bandung: tidak diterbitkan.

Oktaviyanthi, R. Safaah, E., \& Agus, R.N. (2017). Pemberdayaan Keterampilan Guru Matematika dalam Menyusun Bahan Ajar Berbantuan Mathematics Education Software. Wikrama Parahtita: Jurnal Pengabdian Masyarakat, 1 (1), 19-24.

Pranowo, S.D.H. (2017). Pengembangan Aplikasi "BBM" Kimia Sebagai Media Pembelajaran Siswa Kelas X SMA Negeri 1 Ketungau Hulu. Makalah SMAN Ketungau Hulu. Kalimantan Barat: tidak diterbitkan.

Russeffendi. (1991). Pengantar kepada Membantu Guru Mengembangkan Kompetensinya dalam Pengajaran Matematika untuk Meningkatkan CBSA. Bandung: Tarsito.

Saefullah, I. (2016). Membuat Buku Digital Mandiri. Jakarta: Kainoe Books.

Sugiyono. (2015). Metode Penelitian Pendidikan (Pendekatan Kuantitatif, Kualitatif dan $R \& D)$. Penerbit CV. Alfabeta: Bandung.

Tamimudin. (2013). EPUB: Format Buku Digital Masa Depan, (Online), (https://p4tkmatematika.org/2013/12/epub-format-buku-digital-masadepan, diakses Julu 2018).

Thiagarajan, S., dkk. (1974). Instructional Development for Training Teachers of Exceptional Children. Washinton DC: National Center for Improvement Educational System.

Wahyudi, D. (2012). Penerapan pembelajaran metakognitif untuk meningkatkan kemampuan komunikasi matematika siswa kelas X-2 SMAN 1 Rangkasbitung pokok bahasan dimensi tiga Tahun Pelajaran 2015/2016. Makalah SMAN Rangkasbitung. Rangkasbitung: tidak diterbitkan. 